DOI https://doi.org/10.30525/978-9934-571-83-1-28

\title{
СУЧАСНИЙ ПОГЛЯД НА АКТУАЛЬНІ ПРОБЛЕМИ ПРОТИДІЇ МОБІНГУ В ТРУДОВИХ ВІДНОСИНАХ
}

\author{
Трюхан О. А.
}

\section{ВСТУП}

Варто зазначити, передусім, що Основний Закон проголошує: людина, iї життя і здоров'я, честь і гідність, недоторканність і безпека визнаються в Україні найвищою соціальною цінністю (ст. 3). Важливою також є норма Конституції України, яка закріплює право кожного громадянина на повагу до його гідності. Ніхто не може бути підданий катуванню, жорстокому, нелюдському або такому, що принижує його гідність, поводженню чи покаранню (ст. 28) ${ }^{1}$.

Актуальність теми цього дослідження полягає в тому, що в сучасних умовах досить часто доводиться стикатися з тим, що «моральні утиски» на робочому місці та відсутність правових способів їх попередження i боротьби з ними призводять до погіршення психологічного та фізичного стану здоров'я працівників, зниження продуктивності праці, збитків підприємства та інших негативних наслідків як для працівників, так і для роботодавців.

Посилює актуальність цієї тематики та обставина, що в Україні на законодавчому рівні поняття «мобінг» не визначено. Але є інші терміни для його визначення: «психологічний пресинг», «психологічний тиск», «дискримінація щодо співробітника», «утиски на робочому місці». Так, Закон України «Про засади запобігання та протидії дискримінації в Україні» від 06.09.2012 р. визначає не тільки організаційно-правові засади запобігання та протидії дискримінації 3 метою забезпечення рівних можливостей щодо реалізації прав і свобод людини і громадянина, а також містить поняття «утиск» як небажану для особи та/або групи осіб поведінку, метою або наслідком якої є приниження їх людської гідності за певними ознаками або створення стосовно такої особи чи групи осіб напруженої ворожої, образливої або зневажливої атмосфери ${ }^{2}$. Аналізуючи зазначене положення, підкреслимо, що воно хоча й наближене до суті мобінгу, не закріплює жодної форми протидії щодо нього.

\footnotetext{
${ }^{1}$ Конституція України від 28 червня 1996 р. Відомості Верховної Ради Украӥни. 1996. № 30. Ст. 141.

2 Про засади запобігання та протидії дискримінації в Україні: Закон України від 06.09.2012 р. № 5207-VI. Офіиіийний вісник України. 2012. № 76. Ст. 3071.
} 
Мобінг як наукова проблема представлений у працях учених 3. Фрейда, С. Бродського, О. Байло, К. Нідла, С. Василюка, Д. Леонтьєва, А. Маклакова, С. Посолохова, Д. Лейна, Х. Леймана, К. Лоренца, Б. Уілсона, А. Сковитина, К. Батаєвої, Д. Сорокіної, Є. Догаєва, I. Кисельова, М. Галсанова, Н. Чередніченко та ін. Булінг досліджували такі вчені, як Д. Ольвеус, Ю. Щербакова, М. Бутовська, О. Глазманова, Л. Кішлі та ін. Незважаючи на наявність певних наукових праць щодо боротьби з мобінгом, проблема морального переслідування на робочому місці не є до кінця вивченою і дослідженою, а деякі проблеми у цій сфері залишаються невирішеними. Отже, враховуючи наукові праці та рекомендації вчених, доцільно продовжити дослідження 3 цієї проблематики.

Однією з проблем у контексті реалізації працівником свого права на гідність, тобто забезпечення умов, що сприяють нормальній трудовій активності, $\epsilon$ проблема психологічного тиску, або «мобінгу». Варто зазначити той факт, що таке явище, як мобінг, дедалі частішає в трудовому процесі. Ученими проведено чимало досліджень за цією тематикою. Так, під мобінгом варто розуміти систематичне цькування, психологічний терор, форми зниження авторитету та психологічного тиску у вигляді цькування співробітника у колективі, зазвичай із метою його звільнення. Доцільно зазначити, що задля досягнення мети користуються багатьма засобами впливу. На жаль, у XXI ст. це явище набуло особливої актуальності. Крім того, на зазначену тему навіть пишуть книги. Так, у 1998 р. Міжнародне бюро праці видало книгу «Насильство на роботі» ("Violence at Work").

3 огляду на вищевикладене, метою та завданням дослідження $\epsilon$ визначення сутності соціального явища мобінгу, аналіз зарубіжних підходів до законодавчого регулювання протидії мобінгу на робочому місці, вироблення рекомендацій та пропозицій щодо запобігання i подолання морального переслідування серед підлеглих та 3'ясування оптимальних шляхів реформування трудового законодавства щодо захисту працівників, які піддаються психологічному насиллю на робочому місці.

\section{1. Поняття та форми прояву мобінгу у трудових відносинах}

Один із головних чинників, що впливає на працездатність, - атмосфера в колективі. В одній зі своїх наукових праць О. Кравченко абсолютно правильно підкреслює, що повага до людини, яка виконує свою трудову функцію, надає галузі трудового права гуманістичний характер ${ }^{3}$. Утім,

\footnotetext{
3 Кравченко О. Мобінг у трудовому праві. URL: https:/www.socosvita.kiev.ua/sites/default/files/ Visnyk_3_2018-90-91.pdf.
} 
реалії сьогодення дозволяють констатувати той факт, що в останні роки широкої популярності набув такий термін, як «мобінг». Так, «мобінг» як науковий термін вперше ввів у 1958 р. К. Лоренц. Зазначимо, що сам термін «мобінг» походить від англійського іменника "тоb" (натовп) та латинського виразу, який можна перекласти як «бунтуючий натовп». Це явище характерне для будь-якого колективу, починаючи від дитячого до дорослого незалежно від сфери діяльності.

У літературі звертається увага на те, що поняття «мобінг» у трудових правовідносинах було запропоновано шведським психологом і вчениммедиком X. Лейманом. Саме в 80-х pp. XX ст. у своєму монографічному дослідженні «Мобінг, переслідування на роботі» вчений визначив цю категорію як психологічний тиск на робочому місці, який проявляється у цькуванні, чварах, підсиджуванні, плітках, інтригах, хамстві, емоційному насильстві, сексуальному домаганні.

Деякі вчені, які працюють над цією проблемою, зокрема Н.В. Замятіна та Г.В. Долга, визначають мобінг як деструктивну стратегію поведінки персоналу, що призводить до гострого міжособистісного конфлікту, який відрізняється своєю специфічністю та тривалістю і спрямований проти окремого співробітника та/або керівником ${ }^{4}$.

Загальновідомо, що у кожному колективі разом із позитивними мають місце негативні соціально-психологічні процеси та явища, які є наслідком суперечливості людської натури та проблемних міжособистісних стосунків. Людям, які реально перенесли моральний пресинг на роботі, не доведеться пояснювати, що таке мобінг на робочому місці. Спогади про цей період життя є досить неприємними. I навіть якщо таке слово, як «мобінг», ви ніколи не чули, із ситуацією, описаною ним, напевно, зустрічалися, і неодноразово. Цілком ймовірно, що хтось став жертвою мобінгу, комусь дісталася роль ініціатора пресингу, а хтось був просто спостерігачем, хоч і мимоволі. Деякі фахівці констатують, що тих осіб, які спостерігають за конфліктом, переповнює почуття страху, i, щоб не стати наступною жертвою мобінгу, що доволі часто буває на практиці, вони не втручаються в конфлікт.

Жертвою мобінгу може стати, по суті, будь-який «неугодний» співробітник, який із будь-яких причин не сподобався керівнику або решті колективу. Окрім цього, жертвою таких гонінь може бути працівник і у разі недотримання ним негласних правил колективу. Саме такі люди швидко потрапляють до групи ризику.

\footnotetext{
4 Замятіна Н.В., Долга Г.В. Теоретичні аспекти явища мобінгу у трудових колективах. Вісник Чернівецького торговельно-економічного інституту. Економічні науки. 2015. Вип. 3. С. 98-106.
} 
Не варто думати, що жертви мобінгу самі винні в тому, як до них ставляться. Будь-хто може піддатися «моральному терору» на роботі. Німецька дослідниця мобінгу Б. Мешкустат зазначає, що у двох третин «тероризованих працівників» знижується мотивація до праці, більше одного відсотка пропускають роботу через різноманітні захворювання. У результаті третина працівників змінюе роботу в межах свого підприємства, 20\% звільняються самі, $5 \%$ отримують пониження в посаді. Як бачимо, статистика показує, що національність, раса, соціальний i сімейний стан, вік і навіть професійний рівень не можуть захистити від мобінгу.

В Україні, за статистикою, кожна друга особа також стикається 3 цією проблемою щодня. На підтвердження цього у 2013 р. інтернет-газета Тиждень.иа визначила, що в Україні майже $46 \%$ опитаним доводилось бути в ролі жертви мобінгу; зазначимо, що з кожним роком цей показник росте. Майже стільки ж респондентів спостерігали таке явище в колективі, де працювали. Крім того, зізнались у безпосередній участі на боці «агресора» тільки 9\% респондентів ${ }^{5}$. Як бачимо зі статистики, в Україні рівень морального переслідування на робочому місці $є$ досить високим, що не може не викликати занепокоєння. Хоча вважаємо, що насправді наведені цифри більші, бо працівники з цього приводу мовчать або просто залишають місце роботи, не вказуючи справжньої причини. Отже, зважаючи на вищезазначені показники, вважаємо: нині є нагальна потреба вдосконалити законодавство щодо захисту працівників від мобінгу на робочому місці.

У першу чергу, задля з'ясування оптимальних шляхів реформування трудового законодавства щодо захисту працівників, які піддаються психологічному насиллю на робочому місці, варто розглянути причини їх виникнення. Так, аналіз наукової літератури з цієї проблематики дає змогу виділити основні причини мобінгу: біологічні, психологічні, управлінські, соціальні, соціокультурні, комунікативні. Окрім того, психологи стверджують, що мобінг як провідне явище наявний із трьох причин: 1) до нього не ставляться як до серйозної проблеми $\mathrm{i}$, можливо, заперечують як таку; 2) він виходить від самого керівництва; 3) жертви перестають боротися через знесилення постійним цькуванням.

Доречно наголосити на тому, що у літературі виділяють низку основних різновидів мобінгу. Так, залежно від сфери дії виділяють горизонтальний та вертикальний мобінг. Основним різновидом мобінгу, що є характерним для управлінської діяльності, є мобінг серед колег - це горизонтальний

5 В Україні 40\% офіційних працівників потерпають від несправедливої критики на роботі. Тиждень.иа. URL: http: //tyrhden. ua/News/83021. 
мобінг. Цей вид мобінгу полягає в колективному тиску на одного з колег, цькуванні та ігноруванні, тобто такий вид мобінгу є всередині трудового колективу, на рівні професійної групи ${ }^{6}$.

Також виділяють вертикальний мобінг, який відбувається у площині «керівник - підлеглі» і може проявлятися у двох видах: колективний тиск на керівника з боку підлеглих або ж вчинення тиску керівником на весь колектив або окремого його члена.

Окрім того, у науковій літературі виділяють такий вид мобінгу, як подвійний мобінг, або «сендвіч-мобінг», який проявляється у тиску на одного з працівників і вчинений одночасно колегами і керівником.

Що стосується різновиду мобінгу «керівник проти підлеглого», то в літературі його називають «босингом» (від англ. «bossing»). За оцінкою окремих фахівців із вищезазначеної проблеми, у понад 50\% випадків керівник сам ініціює ці події. Зазначимо, що босинг має місце, якщо керівник шляхом зловживання владою тисне на окремого працівника або на весь колектив. Доцільно виділити основні форми босингу, зокрема, це пред'явлення підлеглим занижених або завищених вимог, постійний контроль, обмеження повноважень, постійна зміна виробничих завдань та ін. Таким чином, керівник хоче підвищити власний авторитет і спростити підпорядкування. Іноді здається, що суть нашого українського мобінгу «бояться - значить, поважають».

Варто назвати ще одну форму мобінгу - мобінг підлеглих проти керівника, який ще називають «стафінгом» (від англ. "staffing”). Зазначена форма зустрічається нечасто. Це, наприклад, випадки, коли роботодавець призначає керівником людину, яка може «відштовхувати» підлеглих через авторитарний стиль керівництва.

Необхідно враховувати також як умисний свідомий, так і несвідомий мобінг. Коли має місце другий вид мобінгу, людина, не усвідомлюючи, перетворюється на мобера - вона просто не може приховати свого роздратування стосовно одного з колег.

Ще одним різновидом мобінгу є булінг. Зупинимось детальніше на цьому явищі. Назва «булінг» походить від англійського слова "bully”, яке означає «хуліган, людина, яка використовує свою силу і владу, щоб налякати або заподіяти шкоду слабшим людям».

У науковій літературі, яка присвячена питанням булінгу, представлена низка визначень цього явища. Слово булінг (bullying) означає агресивну поведінку однієї людини стосовно іншої людини з метою заподіяти їй моральну або фізичну шкоду, принизити їі і в такий спосіб утвердити свою владу. Так, норвезький психолог Д. Ольвеус розкриває сутність терміна

\footnotetext{
${ }^{6}$ Чередніченко Н.А. Моббінг і буллінг у трудовому процесі. Право і безпека. 2012. № 3. С. 285-288.
} 
«булінг» та підкреслює три важливих компоненти, що входять до складу явища «боулінг»: 1) булінг - це агресивна поведінка, що містить небажані негативні дії; 2) булінг являє собою модель поведінки, що неодноразово повторюється в часі; 3) булінг - це дисбаланс влади й сили.

Вказана проблематика була предметом дослідження X. Леймана. Вчений визначає булінг як соціальну взаємодію, через яку одна людина (а іноді кілька) зазнає нападів із боку іншої людини (іноді кількох, але, як правило, не більше чотирьох) майже щодня впродовж тривалого періоду (кількох місяців), що викликає у жертви стан безпорадності і виключення з групи ${ }^{7}$.

Булінг є явищем інтернаціональним і досліджується вченими багатьох країн: Америки, Великої Британії, Канади, Норвегії, Фінляндії та інших. Так, термін «булінг» уперше використав англійський журналіст Е. Адамс у 1990 p. для позначення цього явища. Саме тоді й з'явилось словосполучення «булінг на робочому місці» (тиск на робочому місці).

Явище булінгу досить часто зустрічається в трудових колективах, проте ця поведінка бере свої витоки у молодшому підлітковому віці, коли одним 3 основних агентів гендерної соціалізації $\epsilon$ школа ${ }^{8}$.

Так, Ю.Е. Щербакова в одній зі своїх наукових праць вказує, що в західній науці поняття «булінг» визначається як агресивна поведінка роботодавця стосовно найманого працівника, що проявляється у зловмисному переслідуванні, жорстокості, приниженні честі, гідності та ділової репутації працівника, відсутності делегування повноважень i безпідставному вказуванні на службову невідповідність і некомпетентність ${ }^{9}$.

Схожої аргументації дотримується Л. Кішлі. Так, автор стверджує, що булінг - це агресивна поведінка, яка спрямована на приниження почуттів, висловлювання негативних емоцій $\mathrm{i}$ принизливих оцінок щодо іншої людини ${ }^{10}$. Окрім цього, також вказується на те, що основною характеристикою булінгу є емоційне приниження, образа почуттів людини, що призводить до виключення іiї з групи. Зазначається, що агресор посідає вище становище, ніж його жертва, i, відповідно, дозволяє собі дії, що принижують гідність і завдають моральної або фізичної шкоди іншій людині. Зазначена наукова позиція, на нашу думку, заслуговує на підтримку.

За результатами свого дослідження автором було отримано результати, зокрема визначено деякі ознаки булінгу. Насамперед, це емоційне приниження, яке містить вербальні і невербальні способи вираження.

\footnotetext{
${ }^{7}$ Leymann H. The Mobbing Encyclopaedia. URL: www.leymann.se/English/frame.html.

${ }^{8}$ Кон И.С. Что такое буллинг и как с ним бороться? Семья и школа. 2006. № 11. С. 15-17.

9 Щербакова Ю.Е. Проблема мобінгу та булінгу в системі управління персоналом. Право $і$ безпека. 2012. № 5. C. 285-288.

${ }^{10}$ Randall P. Bullying in Adulthood: Assessing the Bullies and Their Victims. Florence, KY, USA: BrunnerRoutledge, 2001. URL: http:/site.ebrary.com/lib/bckharkiv/Doc?id=10.
} 
Акцентується на тому, що вербальні способи - це негативно забарвлені висловлювання, використання підвищеного тону, крик, звинувачення у помилках, приниження здобутків і досягнень людини. Своєю чергою, на думку автора, невербальні способи - це зневажливий погляд, мовчазне засудження, образливі жести тощо. Наступною ознакою булінгу $\epsilon$ втручання у приватне життя людини, а також непривітна і недовірлива поведінка, яка класифікується автором як булінг. На переконання автора, якщо наслідком агресивного, негативного ставлення до людини $\epsilon$ погіршення психологічного i фізичного стану цієї людини, то така поведінка визначається як булінг. Автор стверджує: якщо агресор має намір завдати шкоди іншій людині або дозволяє чи сприяє, щоб ця людина пережила травмуючі події, ця поведінка також є булінгом.

Позитивним моментом є те, що 19 січня 2019 р. набув чинності Закон України «Про внесення змін до деяких законодавчих актів України щодо протидії булінгу (цькуванню)» від 18 грудня 2018 р. № 2657-VIII, в якому визначається поняття булінгу (цькування), щоправда, у навчальноосвітньому процесі. Так, зазначеним вище Законом України передбачено, що ч. 1 ст. 1 Закону України «Про освіту» доповнена пунктом, в якому зазначається, що булінг (цькування) - діяння (дії або бездіяльність) учасників освітнього процесу, які полягають у психологічному, фізичному, економічному, сексуальному насильстві, у тому числі із застосуванням засобів електронних комунікацій, що вчиняються стосовно малолітньої чи неповнолітньої особи та (або) такою особою стосовно інших учасників освітнього процесу, внаслідок чого могла бути чи була заподіяна шкода психічному або фізичному здоров'ю потерпілого ${ }^{11}$.

Окрім цього, Закон України «Про освіту» (ст. 1) також передбачає типові ознаки булінгу, зокрема систематичність (повторюваність) діяння; наявність сторін - кривдник (булер), потерпілий (жертва булінгу), спостерігачі (за наявності); дії або бездіяльність кривдника, наслідком яких $\epsilon$ заподіяння психічної та/або фізичної шкоди, приниження, страх, тривога, підпорядкування потерпілого інтересам кривдника або спричинення соціальної ізоляції потерпілого ${ }^{12}$. Крім цього, внесено відповідні доповнення до статей Закону України «Про освіту», які визначають права та обов'язки засновника та керівника закладу освіти, педагогічних, науково-педагогічних і наукових працівників, інших осіб, які залучаються до освітнього процесу здобувачів освіти та їхніх батьків. Зокрема, передбачається Законом, що керівник закладу освіти має забезпечувати

\footnotetext{
${ }^{11}$ Про внесення змін до деяких законодавчих актів України щодо протидії булінгу (цькуванню) : Закон України від 18 грудня 2018 р. № 2657-VIII. Офіційний вісник України. 2019. № 8.

${ }^{12}$ Про освіту : Закон України від 05.09.2017 p. № 2145-VIII. Відомості Верховної Ради Украӥни. 2017. № 38-39. Ст. 380 .
} 
створення у закладі освіти безпечного освітнього середовища, вільного від насильства та булінгу (цькування). Зміни щодо протидії булінгу внесено до низки спеціальних законів України.

Вартий уваги той факт, що в Україні 11 лютого 2019 р. Бориспільський міськрайонний суд Київської області ухвалив перше рішення у справі № 359/933/19 про булінг, яке внесено до Єдиного державного реєстру судових рішень. Зокрема, встановлено винну особу та накладено штраф у розмірі 850 грн. за вчинення протиправних дій щодо своїх ровесників у навчальному закладі. Відтепер в Україні КУпАП доповнено статтею $173^{4}$, якою передбачено за булінг (цькування) накладення штрафу від п'ятдесяти до ста неоподатковуваних мінімумів доходів громадян або громадські роботи від двадцяти до сорока годин.

Окремо необхідно зазначити, що 13 березня 2019 р. під час засідання Комітет Верховної Ради України з питань науки і освіти розглянув та підтримав проект Закону «Про внесення змін до деяких законодавчих актів України щодо вдосконалення законодавства щодо протидії булінгу стосовно всіх учасників освітнього процесу» р. № 10086 від 26.02.2019 р. (н.д. О. Білозір та ін.). Метою законопроекту є захист прав всіх учасників освітнього процесу від булінгу (цькування) та запровадження адміністративної відповідальності за такі дії для здобувачів освіти або педагогічних, науково-педагогічних, наукових працівників або батьків (або одного з батьків) здобувачів освіти або опікунів (або одного з опікунів) або фізичної особи, яка провадить освітню діяльність.

На нашу думку, сам факт прийняття закону - це вже успіх, оскільки він вкотре заявляє про проблему булінгу (цькування), а тому вимагає ще більше замислитись і застосовувати інші дії з метою профілактики булінгу не тільки в освітньому процесі, але й у трудових відносинах.

Повертаючись до питання різновидів мобінгу, зазначимо, що у наш час з'явилося таке поняття, як «кібербулінг» та «кібермобінг» - «травля» через інтернет, електронну пошту, SMS, переслідування через цифрові технології, розміщення агресивних фото та відео тощо. Сам термін походить 3 англійської мови (від англ. CyberMobbing), також може вживатися як інтернет-мобінг або кібербулінг, під яким розуміють умисні образи, погрози i дифамації та повідомлення іншим даних, що компрометують, за допомогою сучасних засобів комунікації, як правило, протягом тривалого періоду часу. Найбільш поширені види кібербулінгу: наклеп - образлива i неправдива інформація; ізоляція - насильне виключення із віртуальних груп; напад - велика кількість образливих повідомлень, електронних листів, що відправлені жертві; хепіслепінг - 
фізичний напад, побиття жертви, водночас все знімають на фото або відео, які потім розміщують в інтернеті.

За своїми наслідками проблема під назвою «кібермобінг» стрімко набула всесвітнього масштабу кілька років тому. Кібермобінг здійснюється в інформаційному просторі через інформаційно-комунікаційні канали i засоби, у тому числі через інтернет. Особи, що вчиняють ці хуліганські дії, яких часто називають «булер» або «мобер», діють анонімно, тому жертва не знає, від кого походять агресивні дії (але іноді здогадується). Наприклад, якщо якась особа зареєструється в мережі під вигаданим ім'ям і «гратиме» там обрану нею роль, наприклад, займеться тролінгом, то не треба ставитися до цього серйозно. Навпаки, практика показує: чим менше уваги їй приділятимуть, тим швидше особа зникне. Тому одне 3 перших загальних правил мережевого етикету, вироблених ще в той «доісторичний» період, коли соціальні мережі існували у вигляді форумів, - «не годуйте троля» (do not feed the troll). Отже, кібермобінг - це тиск у мережі Інтернет.

Аналізуючи погляди вчених, які працюють над цією проблемою, ми вважаємо, що мобінг - це ситуація психологічного, а іноді й фізичного тиску, який здійснюється 3 метою утисків або цькування частини колективу або окремої персони, яка за будь-яких причин не вписується в загальні норми або правила.

\section{2. Шляхи подолання мобінгу в зарубіжних країнах: досвід для України}

Доцільно звернути увагу на те, що в Європі проблемам мобінгу приділяють значну увагу. Зокрема, у Німеччині у трудових колективах прояви мобінгу стали досліджуватися i активно обговорюватися наприкінці 80-х - на початку 90-х pp. XX ст. Так, у 1997 р. британський Торговий конгрес (Trade Union Congress) організував «гарячу лінію поганого керівника» (Bad Boss Hotline), яка продемонструвала такі результати: $38 \%$ звернень стосувалися знущань із боку керівництва, $25 \%$ несправедливої оплати праці, 15\% жалілися на «рабовласницькі» умови контрактів, $13 \%$ - на неоплачувані понаднормові роботи, $12 \%$ - на необ'єктивне зміщення з посади тощо. На жаль, в Україні такої статистики не ведуть, однак є підстави робити висновки, що відсотки також були б високими. Саме тому в деяких європейських країнах, наприклад у Німеччині, розроблено низку нормативних документів, зокрема вже прийняті закони, постанови, які захищають права працівника у разі моральних переслідувань на робочому місці.

Окрім цього, у Німеччині під час прийняття на роботу мобінг оговорюється у трудовому договорі окремим пунктом. I якщо службовець 
став жертвою цькування на робочому місці, установа виплачує значну матеріальну компенсацію. Вартий уваги той факт, що звільнення працівників, пов'язані 3 утисками на робочому місці, за оцінками експертів, обходяться економіці Німеччини майже в 50 млн євро на рік, зокрема фіксована шкода від «психотерору» в середній фірмі становить $25000-75000$ євро на рік. Щорічно, за оцінками фахівців, «жертвами» мобінгу стають не менше як 1,5 млн осіб (з яких близько 10\% вчиняють самогубство).

Цікавим щодо правового регулювання подолання мобінгу є досвід Німеччини й тому, що прикладом боротьби з мобінгом став випадок, коли суддя зобов'язав виплатити грошову компенсацію «жертві» мобінгу, незважаючи на те, що проти виступали дванадцять свідків. У судовому рішенні було зазначено: «Суспільство, яке допускає мобінг, ставить під сумніви основні постулати демократії».

Варто також зазначити, що, крім Німеччини, проблема мобінгу на робочому місці була також окреслена ще в багатьох країнах Європи. Зокрема, в таких країнах, як Швеція, Франція, Італія, Норвегія, Данія, Бельгія, Шотландія, були прийняті закони, що протидіють мобінгу та захищають працівників від морального переслідування на робочому місці. Так, особливістю трудового законодавства Швеції $\epsilon$ те, що 21 вересня 1993 p. Національним управлінням 3 охорони праці був прийнятий окремий нормативний акт (положення про переслідування за місцем роботи), спрямований на боротьбу з мобінгом на робочому місці, який набув чинності 31 березня 1994 р. Окрім цього, у Швеції та Шотландії у прийнятих законах передбачена кримінальна відповідальність за емоційне знущання.

Доцільно зазначити, що Кодекс праці Польщі також передбачає обов'язок роботодавця протидіяти мобінгу як негативному явищу в трудових відносинах.

У Бельгії також був прийнятий Закон «Про захист від насильства, мобінгу та сексуального домагання на роботі» в 2002 p.

Так, у Норвегії відсутній спеціальний нормативний акт щодо заборони мобінгу, але чинне законодавство було вдосконалене шляхом внесення змін до Закону про захист робочого середовища, який був прийнятий ще у $1977 \mathrm{p}$.

У сфері подолання негативних наслідків, пов'язаних із мобінгом на робочому місці, заслуговує на увагу досвід Франції. Так, у 2002 р. прийнято спеціальний Закон «Про захист працівників від морального переслідування на робочому місці», який передбачає способи захисту права на гідність працівника під час трудової діяльності. Також, як і в 
Німеччині, на багатьох французьких підприємствах та в організаціях мобінг зазначається в трудових договорах. I у разі здійснення психологічного тиску на працівників роботодавець має сплатити досить велику суму грошового відшкодування. Згідно 3 французьким законодавством, той, хто систематично знущається над іншою людиною 3 метою погіршити іiі робочі умови, може бути засуджений до річного тюремного ув'язнення і штрафу до 3750 євро. Так, французька газета $\mathrm{La}$ Tribune наголошує, що стрес співпрацівників щорічно обходиться французьким компаніям у кілька мільярдів євро, а канадським компаніям у 33 млрд канадських доларів на рік ${ }^{13}$.

Як зазначається у ЗМІ (ВВС), паризький прокурор у 2007 р. після тривалого розслідування хвилі самогубств у France Telecom звинуватив та порекомендував притягнути до суду колишнього главу компанії France Telecom i деяких інших ключових співробітників за те, що компанія проводила політику, яка створювала атмосферу тривоги під час болючої реструктуризації, тобто компанія підозрювалася в проведенні політики, внаслідок якої працівників доводили до того, щоб вони залишили місце роботи добровільно (https://www.bbc.com/news/world-europe-44507597). Так, ЗМІ констатують, що під час зборів у 2006 р., на яких були присутні високопоставлені співробітники компанії, були оголошені плани компанії щодо масштабного скорочення у «будь-який спосіб» із метою поліпшення продуктивності праці. 32006 до 2008 р. роботи в корпорації позбулися 22 000 осіб, окрім того, ще 10000 осіб змінили рід діяльності. Профспілка France Telecom звинувачувала у самогубствах керівництво, що реалізувало програму реструктуризації бізнесу компанії в умовах глобальної кризи й падіння прибутків. Так, за інформацією профспілок, 19 співробітників французької телекомунікаційної компанії покінчили життя самогубством в 2008-2009 рр. та залишили передсмертні записки, в яких звинуватили менеджмент France Telecom в тиску на них, 12 спроб самогубства і 8 випадків, пов'язаних із депресією або хворобами. Відомо також, що за три роки покінчили життя самогубством 60 осіб, хоча в деяких публікаціях зазначається, що за 5 років внаслідок здійснення психологічного тиску загинуло 100 осіб (https://tsn.ua/svit/kerivnik-france). Позитивним моментом $\epsilon$ те, що міністр праці розробив національний план запобігання професійному стресу, в якому передбачалось, що кожна компанія зобов'язана підписувати зі своїми працівниками антимобінгові угоди.

Отже, на нашу думку, законодавство Франції стосовно протидії мобінгу $\epsilon$ доволі прогресивним. Вважаємо, що необхідно не тільки активніше вивчати досвід Франції щодо запровадження юридичних механізмів

\footnotetext{
${ }^{13}$ Mental Health at Work: Developing the business case. URL: www.scmh.org.uk.
} 
протидії мобінгу, а й безпосередньо вдосконалювати чинне українське законодавство, бо наявність правових актів Франції спрямована не тільки на захист працівників від мобінгу, а також і на можливості зняття 3 працівника обов'язку доводити факт застосування до нього мобінг-дій.

Як слушно зазначає Л.П. Гаращенко, у правовій системі Італії захист від мобінгу врегульовано не тільки конституційним (ст. 32), але й цивільним законодавством (ст. 35). В Італії термін «мобінг» уперше було застосовано в судовій практиці. Так, у 1999 р. судом м. Турин було розглянуто справу найманого працівника, який звернувся з вимогою відшкодувати шкоду, яку він отримав внаслідок біологічного пошкодження (депресіі), що стала наслідком тяжких умов праці та безперервного й цілеспрямованого переслідування і приниження його з боку керівника відділу. Аналізуючи судову практику Італії, вчена в своїй науковій роботі слушно зазначає, що італійськими судами досить часто розглядаються справи про мобінг. Так, у 24 рішеннях Касаційного суду Італії за шість місяців 2013 р. було використано поняття «мобінг», зокрема італійські суди під мобінгом розуміють протизаконну поведінку. Але головне у таких справах, стверджує вчена, це те, що працівник має довести факти, які свідчать про домагання, шкоду здоров'ю і причинний зв'язок між ними ${ }^{14}$. Необхідно звернути увагу, що на практиці довести факти заподіяння моральної шкоди досить складно.

На нашу думку, досвід європейських країн щодо вдосконалення правового механізму захисту працівників від мобінгу на робочому місці може бути вельми корисний вітчизняному законодавцю на етапі реформування національного трудового законодавства. Вважаємо за необхідне запозичити досвід зарубіжних країн, зокрема Німеччини та Франції, щодо необхідності на вимогу працівника або роботодавця укладати «антимобінгові угоди» 3 обов'язковим конкретним визначенням матеріального відшкодування постраждалій особі.

У вчених є багато думок щодо подолання мобінгу як соціального явища. Так, Н. Калашник стверджує, що уникнути мобінгу практично неможливо, оскільки в будь-якій організації є об'єктивні причини, які можуть сприяти загостренню ситуації ${ }^{15}$. За даними науковців, відсоток прояву мобінгу на підприємствах коливається залежно від галузі. Найбільш високі показники спостерігаються у сфері освіти та здоров'я. Як зазначається в літературі, «найлегшим» наслідком мобінгу для людини є перехід на іншу роботу, а

\footnotetext{
${ }^{14}$ Гаращенко Л.П. Правове регулювання заборони мобінгу в законодавстві зарубіжних країн. URL: http://jrnl.nau.edu.ua/index.php/UV/article/viewFile/1082714448.

15 Калашник Н.С. Місце самоосвіти державних службовців у здійсненні регіональної політики в сучасних умовах. Актуальні проблеми державного управління : зб. наук. пр. Харків : Видавництво НАДУ «Магістр», 2012. № 2 (42). С. 337-345.
} 
найважчим - самогубство. Варто констатувати, що «психологічний терор» дійсно стає актуальним на робочих місцях. Так, на початку грудня 2018 p. у Дарницькому районі столиці сталася трагедія: чоловік викинувся 3 14-го поверху. Родичі чоловіка розповіли, що останнім часом через надмірну вимогливість керівника він практично не спав та став роздратованим. На жаль, як повідомляють ЗМІ (зокрема, блог С. Куценка), історія закінчилась фатально, проте чимало інших випадків самогубства через травлю на роботі можна попередити. Керівник столичної юстиції С. Куценко наголошує, що суїцид - це найстрашніше, до чого може призвести травля на роботі, але такі симптоми, як погіршення емоційного та фізичного стану, недосипання, нервові зриви, пригнічення тощо - це також серйозні сигнали, що на роботі не створені комфортні умови для праці людини ${ }^{16}$. Доцільно наголосити на тому, що роботодавцям необхідно переглянути своє ставлення до працівників та зосередити зусилля на виконанні вимог Конституції України (ст. 68), яка закріплює обов'язок кожного неухильно додержуватися Конституції України та законів України, не посягати на права і свободи, честь і гідність інших людей.

Слушною, на наше переконання, $є$ позиція $Є$. Малигіної - спеціаліста 3 персоналу компанії «Ганза-Україна». Так, вона зазначає: якщо у керівника високі моральні якості, він будуватиме стосунки з людьми на відповідному рівні. Чим нижчий моральний рівень управлінця, який досяг високої позиції, тим гірше він буде вчиняти з підлеглими. Поділяючи загалом зазначену позицію, хотілося б також підкреслити: якщо ж ви відчуваєте, що конфлікт переходить всі межі і вас явно провокують, не опускайтесь до рівня «мобера», а просто ізолюйте себе від ситуації. I щоб захистити себе від морального переслідування на робочому місці, насамперед, на захист своїх можливих помилок виставляйте не емоції, а аргументовані заперечення, адже самі ж наслідки мобінгу, в першу чергу, позначаються на здоров'ї - як психічному, так і фізичному. Тому необхідно поставитись до ситуації вкрай серйозно, інакше це може призвести до нервових зривів, депресій та інших негативних наслідків. Насамперед це стосується новачків у колективі.

Безперечно, не можливо не звернути увагу на те, що найефективніший спосіб боротьби з тиском і грубістю на робочому місці - захист на законодавчому рівні. Варто звернути увагу на той факт, що в Україні у 2014 р. вже були спроби прийняти Закон «Про забезпечення захисту від морального переслідування на робочому місці» від 03.06.2014 р. (реєстр. № 4997). Законопроектом пропонувалося гарантувати право осіб на ефективний захист проти морального переслідування на робочому місці.

\footnotetext{
${ }^{16}$ Блог керівника столичної юстиції Станіслава Куценко URL: https: //ukr.lb.ua/blog/stanislav_kutsenko.
} 
На жаль, 27.11.2014 р. цей законопроект був відкликаний. Так, у 2017 р. комітет Верховної Ради з питань соціальної політики, зайнятості та пенсійного забезпечення рекомендував парламенту прийняти за основу проект Закону про внесення змін до деяких законів України (щодо запобігання мобінгу) від 25.07.2017 р. № 7005. Проектом пропонувалося імплементувати європейське законодавство та внести до КЗпП України, Закону України «Про зайнятість населення» та Кримінального кодексу України поняття «мобінг», врегулювати на законодавчому рівні права та гарантії для працівників, які постраждали від проявів мобінгу на робочому місці. Законопроект №7005 під мобінгом розуміє форму психологічного насилля, яка полягає в тривалому та систематичному цькуванні працівника в колективі, сексуальному домаганні, психологічному тиску на нього 3 метою подальшого звільнення. Варто зазначити, що 07.02.2019 p. законопроект № 7005 також був відкликаний.

Як зазначалось вище, нині в Україні відсутні правові механізми щодо захисту працівників від мобінгу на робочому місці. Тобто особа має право захищатися у суді, наприклад, за наклеп, але виграти такий судовий процес малоймовірно без свідків, доказів та правової бази. Через такі конфлікти на роботі працівникові доводиться звільнятися «за власним бажанням», що насправді не відповідає дійсності. Відновити юридичну справедливість потім украй складно через відсутність закону, який буде захищати честь i гідність людини на робочому місці, незаконність звільнення довести неможливо. Оскільки справи щодо доведення наявності мобінгу у трудових відносинах, які призвели до порушення трудових прав працівників, досить складні.

Судова практика свідчить, що за таких умов позови про визнання звільнення незаконним та поновлення на роботі не задовольняються та суди посилаються на те, що оскільки працівник сам написав заяву на звільнення, це було його волевиявлення. Вважаємо за доцільне погодитись 3 думкою А.А. Сорокіної, яка, аналізуючи окремі судові справи у своєму науковому дослідженні 3 зазначеної проблематики, констатує, що здебільшого суди відмовляють у задоволенні позовних вимог, наводячи у мотивувальній частині різні причини або обмежуючись загальними витягами з текстів ЦПК України та КЗПП України ${ }^{17}$. Автор також звертає увагу, що серед інших причин відмови у задоволенні позову наявні і недоведені факти морального тиску на позивача, зокрема рішення Жовтневого районного суду м. Полтави у справі № 2-1753/08 ${ }^{18}$ та рішення

\footnotetext{
17 Сорокіна А.А. Мобінг та булінг в трудових відносинах. Молодий вчений. 2018. № 11(63). C. $139-145$.

${ }^{18}$ Рішення Жовтневого районного суду м. Полтави у справі №2-1753/08. Сдиний державний реєстр судових рішень. URL: http://reyestr.court.gov.ua/Review/8364808.
} 
Печерського районного суду м. Києва у справі № 2-3851/12 $2^{19}$, і пропуск строку, встановленого у ст. 233 КЗпП України, що змусило написати заяву про звільнення ${ }^{20}$.

Отже, як бачимо, працівники, які й так фактично є слабшою стороною в трудових відносинах, залишаються незахищеними, а іноді й без засобів існування та психологічно пригніченими. Тож доцільно наголосити на тому, що необхідність закону, який буде захищати честь і гідність людини на робочому місці, є очевидною.

Варто нагадати, що у 2006 р. Верховна Рада України ратифікувала один 3 основних документів Ради Європи в галузі прав людини - Європейську соціальну хартію (переглянуту), взявши на себе зобов'язання за 74 пунктами з 98, серед яких обов'язок виконувати і ст. 26, яка закріплює право на гідне ставлення на роботі. Відповідно, сторони зобов'язуються, консультуючись 3 організаціями роботодавців і працівників, поглиблювати поінформованість, поширювати інформацію про систематичні або явно негативні та образливі дії щодо окремих працівників на робочому місці або у зв'язку з виконанням роботи, сприяти запобіганню таких дій і вживати всіх відповідних заходів задля захисту працівників від такої поведінки ${ }^{21}$.

Крім того, в Європейському Союзі діє Директива Ради 2000/78/ЄС, ухвалена Радою від 27.11.2000р., про встановлення загальної системи рівного ставлення у сфері зайнятості та професійної діяльності. У Директиві поведінка, яка має на меті створити ворожу, така, що принижує гідність людини або створює образливу ситуацію, визначена як переслідування працівника і прирівнюється до дискримінації трудових прав ${ }^{22}$.

Як слушно зазначає В.Ф. Пузирний, держава має взяти на себе відповідальність щодо розроблення й впровадження дієвих правових i організаційних механізмів захисту гідності працівників у період трудової діяльності та забезпечення безпечних умов праці в руслі сучасних міжнародних ${ }^{23}$. Отже, гідність працівника у період трудової діяльності є також об'єктом міжнародно-правового захисту.

\footnotetext{
19 Рішення Печерського районного суду м. Києва у справі №2-3851/12. Єдиний державний реєстр судових рішень. URL: http://reyestr.court.gov.ua/Review/28793517.

${ }^{20}$ Рішення Заводського районного суду м. Запоріжжя у справі № 332/3394/15-ц. Сдиний державний реєстр судових рішень. URL: http://reyestr.court.gov.ua/Review/53882104.

21 Про ратифікацію Європейської соціальної хартії (переглянутої) : Закон України від 14.09.2006 р. № 137-V. Офіиіийний вісник Украӥни. 2006. № 40. Ст. 2660.

22 Про встановлення загальної системи рівного відношення у сфері зайнятості та професійної діяльності: Директива Ради 2000/78/СС від 27.11.2000 p. Офіиійний вісник СС. 2000. № L180. C. $22-26$.

23 Пузирний В.Ф. Захист від мобінгу в трудових відносинах. URL: http://repositsc.nuczu.edu.ua/ bitstream/123456789/7723/1202018.pdf.
} 
Вартий уваги той факт, що 01.03.2019 р. у Верховній Раді зареєстровано проект закону № 10118 про внесення змін до деяких законодавчих актів України щодо протидії мобінгу. Законопроект має на меті не тільки надати цьому явищу належного правового закріплення та захистити учасників трудових відносин від різних форм мобінгу, а також встановити адміністративну відповідальність за такі дії шляхом внесення відповідних змін до КУпАП. Проект закону № 10118 визначає мобінг як діяння учасників трудових відносин, які полягають у психологічному, фізичному, економічному насильстві, у тому числі із застосуванням засобів електронних комунікацій, що вчиняються стосовно працівника підприємства, установи, організації незалежно від форм власності, виду діяльності і галузевої належності, а також осіб, які працюють за трудовим договором із фізичними особами або такою особою стосовно інших учасників трудових відносин із метою приниження їх людської гідності за певними ознаками, створення стосовно них напруженої, ворожої, образливої атмосфери та примушування учасника трудових відносин до зміни місця роботи ${ }^{24}$.

Відповідно до законопроекту № 10118 цькування на роботі тягне за собою накладення штрафу від 50 до 100 неоподатковуваних мінімумів доходів громадян (від 850 до 1700 грн.) або громадські роботи на строк від 20 до 40 годин. Мобінг, вчинений групою осіб або повторно протягом року після накладення адміністративного стягнення, тягне за собою накладення штрафу від 100 до 200 таких мінімумів (від 1700 до 3400 грн.) або громадські роботи на строк від 40 до 60 годин. Також автори законопроекту пропонують передбачити покарання за неповідомлення власником про випадки мобінгу до Національної поліції. Передбачено внесення змін до КЗпП України та Закону України «Про колективні договори і угоди», а також до антидискримінаційного законодавства у частині врегулювання питання протидії мобінгу, зокрема у Законі України «Про засади та протидії дискримінації в Україні» мобінг зарахований до форм дискримінації.

Зазначене вище, своєю чергою, зумовлює необхідність удосконалення трудового законодавства. На нашу думку, 3 урахуванням зарубіжного досвіду необхідно передбачити й кримінальну відповідальність за систематичне застосування елементів мобінгу, наслідком якого $\epsilon$ звільнення працівника. Сподіваємось, що 3 прийняттям законопроекту № 10118 про внесення змін до деяких законодавчих актів України щодо

\footnotetext{
${ }^{24}$ Проект Закону про внесення змін до деяких законодавчих актів України щодо протидії мобінгу (реєстр. № 10118) текст законопроекту від 01.03 .2019 p. URL: http://w1.c1.rada.gov.ua/pls/ zweb2/webproc4_1?pf3511=65602.
} 
протидії мобінгу буде гарантоване право на ефективний захист від морального переслідування на робочому місці.

\section{ВИСНОВКИ}

Підсумовуючи вищевикладене, можна дійти висновку, що мобінг - це різновид морального насильства. Найчастіше саме цей вид насильства стає засобом, що примушує людину залишити робоче місце. Як зазначалось вище, моральне переслідування на робочому місці $\epsilon$ одним із видів дискримінації, заборона якої вже передбачена законодавством України, зокрема Законом України «Про засади запобігання та протидії дискримінації в Україні» від 06.09.2012 р. Отже, поданий законопроект № 10118 є невід'ємною складовою частино законодавства про працю. Через відсутність в Україні правового механізму захисту працівників від мобінгу на робочому місці, на нашу думку, необхідність прийняття закону, який буде гарантувати право працівників на ефективний захист від мобінгу на робочому місці, є очевидною та актуальною, адже законопроект, у разі його прийняття, не тільки узгодить національне законодавство із положенням Європейської соціальної хартії (переглянутої), а й забезпечить гідне ставлення до працівників на роботі завдяки впровадженню правових засобів захисту від морального переслідування на робочому місці, а також буде сприяти підтриманню психологічного та фізичного стану працівників, покращенню психологічного клімату та підвищенню продуктивності праці на підприємстві загалом.

Щодо перспективного трудового законодавства, то, проаналізувавши проект Трудового кодексу № 1658, можна дійти висновку: проект ТК не містить ні поняття «мобінг», ні заходів його попередження. С лише деякі згадування щодо неприпустимості дій роботодавця, спрямовані на припинення трудових відносин за власною ініціативою працівника проти його волі (п. 15 ст. 2). У зв'язку з цим важливо вдосконалювати правовий механізм захисту працівників у зазначеній сфері. На нашу думку, у проекті ТК України необхідно визначити поняття «мобінг» як діяльність або поведінку осіб, які є членами трудового колективу, що скерована проти працівника і полягає у довготривалому переслідуванні або залякуванні працівника 3 метою приниження, безпідставної критики, поширення завідомо неправдивої інформації, формування у працівника заниженої оцінки професійної придатності, а також примушення постраждалої особи до звільнення 3 місця роботи. Видається доцільним також, що, крім поняття «мобінг», у перспективне трудове законодавство необхідно внести також поняття «булінг». Адже, на жаль, таке явище, як булінг, дійсно стає дедалі частішим у трудовому процесі. 
3 метою запобігання морального переслідування на робочому місці вважаємо, що у проекті ТК має бути встановлена чітка заборона щодо морального переслідування на робочому місці, необхідно передбачити процедуру звернення працівників у разі вчинення роботодавцем морального тиску у професійному середовищі до відповідних органів із відповідною заявою/скаргою про відновлення порушених прав. Окрім цього, необхідно передбачити змогу поновити працівника на роботі за рішенням суду, визнати недійсним звільнення працівника за власним бажанням i зобов'язати роботодавця відшкодувати матеріальну і моральну шкоду.

На наш погляд, із метою протидії мобінгу у колективі у перспективному трудовому законодавстві варто врегулювати питання чіткої процедури притягнення до відповідальності працівників, застосування дисциплінарних стягнень, а також позбавлення премій працівників, які умисно свідомо вчиняють протиправні дії щодо своїх колег, або тиснуть на окремого працівника, або на весь колектив. Окрім того, вважаємо за необхідне передбачити не тільки обов'язок роботодавця захищати працівників від мобінгу всередині трудового колективу, а також передбачити відповідальність роботодавця за порушення законодавства про захист від морального переслідування на робочому місці.

\section{АНОТАЦІЯ}

У статті розглянуто сучасні наукові погляди на актуальні проблеми протидії мобінгу в трудових відносинах, розкрито поняття та суть мобінгу. Досліджено форми прояву мобінгу, розглянуто причини його виникнення й визначено напрями їх профілактики та подолання. Обгрунтовано, що проблема відновлення порушених прав працівників залишається вкрай гострою й актуальною. Констатовано, що найефективніший спосіб боротьби з тиском і грубістю на робочому місці - захист на законодавчому рівні. Досліджена низка наукових публікацій із цієї проблематики, що містять пропозиції вчених щодо вдосконалення перспективного трудового законодавства стосовно проявів мобінгу в професійному середовищі. Проаналізовано чинне законодавство кількох зарубіжних країн про заборону мобінгу на робочому місці та сформульовано висновок: позитивний досвід розвинутих країн щодо правового механізму захисту працівників від мобінгу на робочому місці може бути вельми корисним для вітчизняного законодавця на етапі реформування національного трудового законодавства. Тож, потрібно його не тільки вивчати, але й запроваджувати в Україні з метою покращення умов праці. Також зроблені загальні висновки та надані пропозиції щодо вдосконалення правового регулювання в цій сфері. 


\section{ЛІТЕРАТУРА}

1. Конституція України від 28 червня 1996 р. Відомості Верховної Ради України. 1996. № 30. Ст. 141.

2. Про засади запобігання та протидії дискримінації в Україні : Закон України від 06.09.2012 р. № 5207-VI. Офічійний вісник України. 2012. № 76. Ст. 3071.

3. Кравченко O. Мобінг у трудовому праві. URL: https: //www.socosvita.kiev.ua/sites/default/files/Visnyk_3_2018.

4. Замятіна Н.В., Долга Г.В. Теоретичні аспекти явища мобінгу у трудових колективах. Вісник Чернівецького торговельно-економічного інституту. Економічні науки. 2015. Вип. 3. С. 98-106.

5. В Україні 40\% офіційних працівників потерпають від несправедливої критики на роботі. Тиждень.иа. URL: http: //tyrhden.ua/News/83021.

6. Чередніченко Н.А. Моббінг i буллінг у трудовому процесі. Право і безпека. 2012. № 3. С. 285-288.

7. Leymann H. The Mobbing Encyclopaedia. URL: www.leymann.se/English/frame.html.

8. Кон И.С. Что такое буллинг и как с ним бороться? Семья и школа. 2006. № 11. С. 15-17.

9. Щербакова Ю.Е. Проблема мобінгу та булінгу в системі управління персоналом. Право і безпека. 2012. № 5. С. 285-288.

10. Randall P. Bullying in Adulthood: Assessing the Bullies and Their Victims. Florence, KY, USA : Brunner-Routledge, 2001. URL: http:/site.ebrary.com/lib/bckharkiv/Doc?id=100535.

11. Про внесення змін до деяких законодавчих актів України щодо протидії булінгу (цькуванню) : Закон України від 18 грудня 2018 р. № 2657-VIII. Офіиійний вісник Украӥни. 2019. № 8.

12. Про освіту : Закон України від 05.09.2017 р. № 2145-VIII. Вiдомості Верховної Ради Украӥни. 2017. № 38-39. Ст. 380.

13. Mental Health at Work: Developing the business case. URL: // www.scmh.org.uk.

14. Гаращенко Л.П. Правове регулювання заборони мобінгу в законодавстві зарубіжних країн. URL: http://jrnl.nau.edu.ua/index.php/UV.

15. Калашник Н.С. Місце самоосвіти державних службовців у здійсненні регіональної політики в сучасних умовах. Актуальні проблеми державного управління : збірник наук. пр. Харків : Видавництво НАДУ «Магістр», 2012. № 2 (42). С. 337-345.

16. Блог керівника столичної юстиції Станіслава Куценка. URL: https: // ukr.lb.ua/blog/stanislav_kutsenko. 
17. Сорокіна А.А. Мобінг та булінг в трудових відносинах. Молодий вчений. 2018. № 11(63). С. 139-145.

18. Рішення Жовтневого районного суду м. Полтави у справі № 2-1753/08. Єдиний державний реєстр судових рішень. URL: http://reyestr.court.gov.ua/Review/8364808.

19. Рішення Печерського районного суду м. Києва у справі № 2-3851/12. Єәиний державний реєстр судових рімень. URL: http://reyestr.court.gov.ua/Review/28793517.

20. Рішення Заводського районного суду м. Запоріжжя у справі № 332/3394/ 15-ц. Єдиний державний реєстр судових рімень. URL: http://reyestr.court.gov.ua/ Review/53882104.

21. Пузирний В.Ф. Захист від мобінгу в трудових відносинах. URL: http://repositsc.nuczu.edu.ua/bitstream/12345.pdf.

22. Проект Закону про внесення змін до деяких законодавчих актів України щодо протидії мобінгу (реєстр. 10118), текст законопроекту від 01.03.2019 p. URL: http://w1.c1.rada.gov.ua.

23. Про ратифікацію Європейської соціальної хартії (переглянутої) : Закон України від 14.09.2006 р. № 137-V. Офіиійний вісник України. 2006. № 40. Ст. 2660.

24. Про встановлення загальної системи рівного відношення у сфері зайнятості та професійної діяльності : Директива Ради 2000/78/СС від 27.11.2000 p. Офіиійний вісник СС. 2000. № L180. C. 22-26.

\section{Information about author:} Triukhan O. A.,

PhD., Associate Professor of the Department of Labour Law and Social Security Law of the National University "Odessa Law Academy" 23, Fontanska Road, Ukraine, Odessa 